\title{
Mindent az alapjövedelemről?
}

\author{
Amy Downes - Stewart Lansley (eds.): It's Basic Income. \\ The Global Debate. Bristol, Policy Press 256 p.
}

\author{
OLÁH ESZTER ${ }^{1}$
}

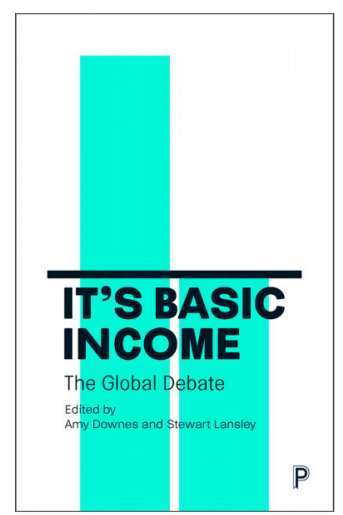

Az egzisztenciális biztonság megteremtése évszázadok óta meghatározza társadalmunk mindennapjait. Az egyénekben jövőterveik kialakításakor aggodalom fogalmazódik meg életszínvonaluk fenntarthatóságával kapcsolatban, hiszen a XXI. századi információtöbbletből nehezen szűrhető ki, hogy milyen változások várhatóak a következő években, melyek hatással lehetnek megélhetésükre.

A jövőbeli terveket elsősorban a munkaerőpiac változásai befolyásolhatják, mint az alulfoglalkoztatás jelensége, a határozott idejû munkaszerződések túlsúlya, a teljes munkaidős állások felszámolása a részmunkaidős állások javára, a prekariátus szélesedése és az alacsony bérek okozta hátrány (Artner 2014, Standing 2014). Ezek a változások a mindennapok átstrukturálásán túl jelentős hatást gyakorolnak a növekvő vagyoni egyenlőtlenségekre és a politikai stabilitásra. További probléma, hogy a munkalehetőségek jövőbeli szűkülését reális jövőképnek tekintik a kutatók, elsősorban a robottechnológia térnyerése miatt (Ford 2017).

Ezek a gazdasági és társadalmi változások a jóléti programokot kihívás elé állítják. Amennyiben a jövőben a munkavégzés veszít elsődleges strukturáló funkciójából, a mai jóléti juttatások alapja is megkérdőjeleződik. Szükség lesz egy olyan koncepció megvalósítására, amely hasonlóan a munkavégzéshez, elősegíti a kedvezményezettek önmegvalósítását és lehetővé teszi a társadalmi integrációt.

Ilyen gazdaságpolitikai eszköz lehet az alapjövedelem, amely már 1516-ban Morus Tamás utópiájában is megjelent, mint az általános, mindenkire kiterjedő jólét eszköze (Morus 1963). Egy olyan univerzálisan járó juttatásról van szó, mely a XXI. században is képes aktualitást nyerni a hétköznapi és a politikai vagy közgazdaságtani diskurzusokban egyaránt, leginkább olyankor, amikor a munka által megszerezhető jövedelem lehetősége korlátozódik.

${ }^{1}$ Doktorandusz, Debreceni Egyetem, Szociológia és Társadalompolitika Doktori Program, e-mail: olah.eszter@arts.unideb.hu 


\section{RECENZIÓ}

Az Amy Downes és Stewart Lansley szerkesztésében megjelent It's Basic Income. The Global Debate (2018) című angol nyelvű könyv arra tesz kísérletet, hogy ábrázolja azt a gazdasági, társadalmi és politikai környezetet, ahol napjainkban felmerül az alapjövedelem gondolata. Továbbá igyekeznek megragadni e gondolatkör filozófiáját, mindazon túl, hogy gyakorlati példákat, kísérleti programokat is ismertetnek, így könnyű olvasmánnyá teszik a néhány oldalas tanulmányokat.

A gyűjteményes kötet hat fő egységből áll és összesen harmincnyolc rövid tanulmányt tartalmaz. Az érintett témák színesek, így segítenek megismerni az alapjövedelem kérdéskörének összetettségét. Az első és második egység a jövőbeli tendenciákat és kihívásokat írja le, amelyek megoldásaként az alapjövedelem gondolata fogalmazódik újra. A harmadik egység az alapjövedelemmel kapcsolatos kritikus hangoknak ad teret. A negyedik és ötödik egységben az alapjövedelem történetét ismerheti meg az olvasó közelebbről, eljutva egészen a legfrissebb kísérleti programokig, amelyekben eltérő koncepciók mentén tesztelik az alapjövedelem gazdaságra és társadalomra gyakorolt hatását.

A választott cím azt szimbolizálja, hogy nem csupán egyetlen történelmi kort és nem csupán egyetlen országot hatott át ennek a tárgykörnek az ideológiája, hanem valóban az egész világot globálisan érintő juttatást takar. Thomas Paine vagy Mark Zuckerberg különböző történelmi korokat képviselnek, mégis mindketten fontosnak tartották képviselni az alapjövedelem eszközét. Továbbá olyan jelentős országok foglalkoztak akár kísérleti programként is ezzel a juttatással, mint az Amerikai Egyesült Államok vagy India.

A szerkesztők már a bevezetésben hangsúlyozzák, hogy a több évszázada felmerülő gazdaságpolitikai eszköz sokak által utópisztikus jelenségként értékelhető. A kötet az alapjövedelem fogalma kapcsán az adómentességet és a feltételnélküliséget hangsúlyozza. Tehát a juttatás független attól, hogy az egyén végez-e munkát, független az egyén körülményeitől, így szociális juttatásként elsődleges célja, hogy az állampolgárok részére egy minimumszintet biztosítson a megélhetés terén.

A bevezető tanulmányt az első egység kilenc rövid írása követi, melyekben bemutatásra kerülnek azok a körülmények, amelyek kapcsán az alapjövedelem mint valódi megoldás kerül előtérbe. Jelentős félelemként fogalmazódik meg a jelenlegi és jövőbeli tendenciákat tekintve, hogy a gyors technológiai változások hatására - a robotika és a mesterséges intelligencia eredményeként - egyre több munkavállaló szorul ki a munkaerőpiacról, későbbiekben megélhetésüket támogathatná az alapjövedelem, véli Martin Ford és Eduardo Rodriguez-Montemayor. A jelenleg működő tendenciák hatására átalakul a munka szerepe az emberek mindennapjaiban, így egyre kevésbé a teljes munkaidő számít az elfogadott normának. A fiatalok rugalmas munkaidővel számolnak és azt várják munkaadójuktól, hogy ezt biztosítsa számukra. Chris Oestereich azt vizsgálja, hogy mindezen változások hogyan hatnak a gazdaság stabilitására. Brian Eno megfogalmazza, hogy az alapjövedelmet sokan idealistának tartják, mivel nehezen megvalósíthatónak tűnik a mai gazdasági és politikai vi- 


\section{RECENZIÓ}

szonyok mellett, mint ahogy korábban a választójog bevezetése is annak tűnt a korábbi történelmi időszakokban. Az első egység kilenc tanulmánya között helyet kaptak még a nők helyzetével foglalkozó írások is, mivel az alapjövedelem bevezetésével kapcsolatban az egyik jelentős várakozás, hogy a közösségért végzett tevékenység vagy a nők családban végzett munkája pénzügyileg is megfizethetővé válna, ez pedig átalakíthatná társadalmunkat, fejezi ki Vanessa Olorenshaw várakozásait. Elősegítené a nemek közötti nagyobb igazságosság megteremtését, ami hatással lenne a családon belüli férfi-nő viszonyra és a nők primer szektorbeli munkavállalására.

A második egységben a jövő társadalmát szemléltető nyolc tanulmány kapott helyet. A jelenlegi és a jövőbeli helyzet leírása e tanulmányokban váltakozva követi egymást. Egyesek azt elemzik, hogy milyen társadalmi változásokat hozna az alapjövedelem bevezetése (például Anthony Painter írása), mások pedig inkább a jelenlegi helyzetre koncentrálnak, a munka jelenlegi megítélésére (Olivia Hanks - Norwich Radical), vagy azt hangsúlyozzák, hogy a jóléti állam válságba került és ezért tekintenek megoldásként az alapjövedelemre (Jonathan Bartley - Caroline Lucas).

A harmadik egység öt tanulmánya az alapjövedelem kritikai megközelítésére fókuszál. A szerkesztők igyekeznek hűek maradni a könyv címéhez: a vita kifejezés elvárásként magában hordozza, hogy az olvasó az érvek és ellenérvek ütköztetéséből formálhat véleményt. A negatívumok között számos kérdés merül fel, amelyekre a tanulmányokban bizonytalan válaszok születnek. Talán ezek a homályos reakciók hozzájárulnak ahhoz, hogy mind a közvéleményben, mind szakértői körökben kialakul egyfajta félelem az alapjövedelemmel szemben. Az egyik legnagyobb aggály a finanszírozhatósága kapcsán merül fel. Sokan kétségbe vonják, hogy az alapjövedelemnek létezik hatékony pénzügyi modellje. Mindemellett Francine Mestrum úgy véli, hogy mivel univerzális alapon járna mindenkinek az alapjövedelem összege, így továbbra is fennmaradnának az egyenlőtlenségek. Ezen túlmenően pedig Peter Beresford megfogalmazza kételyeit az alapjövedelem gazdaságra gyakorolt hatásával kapcsolatban, mivel félő, hogy negatívan hatna az egyének munkavállalási motivációjára egy feltétel nélküli havi juttatás. A munkához való hozzáállás negatív irányba történő változásának rémképe miatt az alapjövedelem ötletét Anke Hassel zsákutcának nevezi, Ed Whitfield pedig egyszerűen nem tartja elég jó ötletnek.

A negyedik egység kilenc tanulmányából közelebbről is megismerheti az olvasó az alapjövedelem múltját, azon gondolatokat, amelyekre épül. Philippe Van Parijs az alapjövedelem kapcsán talán a legtöbbet hivatkozott filozófus és közgazdász, írása helyet kapott a gyüjteményes kötetben. Három fö szempontot fogalmaz meg, mely az alapjövedelem mellett szól: fokozza az egyén szabadságát, előmozdítja az egyetemes jogokat és megvalósítja a gazdasági biztonságot. Andrew Harrop and Fabian Society élesen fejezik ki az alapjövedelem gyakorlati megvalósíthatóságának lényegét, miszerint lehet a hozzá kapcsolódó vita globális szintű, de a reformjavaslatok a lokalitást igénylik, melyek a tényleges helyi szükségletekre fókuszálnak. 


\section{RECENZIÓ}

A kötet utolsó előtti fejezete igyekszik a teljesség igénye nélkül ismertetni néhány frissebb pilot programot, mint például a finn, kanadai vagy a holland modell. Ezek a kísérletek a gyakorlatban kívánják vizsgálni az alapjövedelem hatásait. Mivel a legtöbb pilot program jelenleg még zajlik, az ezekből levonható következtetések és eredmények még váratnak magukra. Arra azonban kiválóan alkalmasak, hogy továbbra is fenntartsák az alapjövedelemmel kapcsolatos diskurzust a közbeszédben.

A könyvben megjelenő múlt-jelen-jövő váltakozó tendenciája azt sugallja, hogy újra és újra felmerülnek az alapjövedelemmel társított alapvető értékek, amelyeknek vágyott elérése képes napirenden tartani ennek a gazdaságpolitika eszköznek a gondolatát. Ilyen érték például az igazságosságra való törekvés vagy a szabadság garantálása. Az ezekre való igény a munka fogalmának átalakulásával még nagyobb hangsúlyt kapnak. Az átalakulással párhuzamosan az új körülményekhez való alkalmazkodást is szükséges kidolgozni, ennek egyik eszköze lehet az alapjövedelem. Erről az eszközről a gondolkodás és a vita fenntartása más innovatív koncepciók kidolgozásához is elvezethet, amelyek talán hatékonyabban orvosolják majd a felmerülő társadalmi és gazdasági problémákat, mint ahogyan azt az alapjövedelem garantálása lehetővé tenné.

A cím ne tévesszen meg senkit: a könyv szerkesztése során a vita elég egyoldalúra sikeredett, a tanulmányok többsége a szerzők pozitív megítélését tükrözi az alapjövedelemmel kapcsolatban. A kötet mindemellett tökéletes választás azoknak, akik szeretnék megismerni az alapjövedelem témakörét, mind elméleti, mind gyakorlati kereteit, annak korai hagyományaitól kezdve a jelenlegi vitákon át, egészen a jövő társadalmára gyakorolt feltételezett pozitív hatásig.

\section{Irodalom}

Artner A. (2014): A feltétel nélküli alapjövedelem relevanciája és kérdőjelei. Eszmélet, 2014/102. 109-130.

Atkinson, A. B. (2017): Egyenlőtlenség. Mit kellene tennünk? Budapest, Kossuth Kiadó.

Ford, M. (2017): Robotok kora. Milyen lesz a világ munkahelyek nélkül? Budapest, HVG Kiadó.

Morus T. (1963): Utópia. Budapest, Magyar Helikon.

Standing, G. (2014): The Precariat. Contexts, 2014(13): 10-12. 